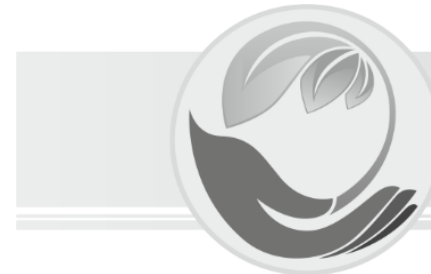

Удк 629:083
Мехатроніка і цифрові технології природокористування Mechatronics and digital technology of nature management

https://doi.org/10.37700/enm.2020.3(17).101 - 110

\title{
Принципи побудови та функціонування кіберфізичної системи технічного сервісу автотранспортної та мобільної сільськогосподарської техніки
}

\author{
В.В. Аулін, А.В. Гриньків, С.В. Лисенко, О.М. Лівіцький, А.О. Головатий, В.О. Дьяченко
}

Центральноукраїнський національний технічний університет, (м. Кропивницький, Україна)

\begin{abstract}
В роботі представлено багаторівневу самоорганізацію ресурсів кіберфізичної системи технічного сервісу на основі ситуаційно-орієнтованого підходу. В основі підходу покладено концепцію, що стосується організаційної поведінки ресурсів верхнього рівня і забезпечення їх врахування при самоорганізації ресурсів нижнього рівня. З'ясовано, що спільний доступ до інформації про ресурси кіберфізичної системи технічного сервісу забезпечується використанням технології інтелектуальних просторів. Реалізацію ситуаційно-орієнтованого підходу здійснено на прикладі сценарію надання послуг в сервісному обслуговуванні автотранспортної та мобільної сільськогосподарської техніки з участю фізичних пристроїв, контрольованих керуючими ресурсами, та ресурсів планування, що відповідають за генерацію спрямованості поведінки керуючих ресурсів. Зазначено, що технологія інтелектуального простору побудована на відкритій платформі Smart-M3 і представлено її структуру. Сама платфрорма грунтується на концепції семантичний Веб. Показано, що обмін інформацією між учасниками просторів здійснюється на основі протоколу НTTP.
\end{abstract}

Ключові слова: кіберфрізична система, технічний сервіс, ситуаційно-орієнтований підхід, самоорганізація, фрізичний простір, інтелектуальний простір, ресурс

Постановка проблеми. Принципи побудови та фоункціонування кіберфрізичної системи (КФС) технічного сервісу автотранспортної (АТT) та мобільної сільськогосподарської техніки (МСГТ) передусім залежать від поведінки ресурсів. Ресурси взаємодіють між собою в інтелектуальному просторі і керуючими пристроями в фрізичному просторі. Все це відбувається в режимі реального часу.

Інтелектуальні та самоорганізуючі КФС технічного сервісу на основі інтелектуальної стратегії технічного обслуговування і ремонту (ТОР) характеризуються можливістю реагування на зміни в фрізичному просторі шляхом децентралізованого прийняття рішень щодо необхідної поведінки фрізичних діагностуючих пристроїв при відсутності зовнішнього управління. Такі системи є особливо стійкими до зовнішніх впливів в силу їхньої здатності до динамічної адаптації і забезпечення свого функціонування $[1,2]$.

Підхід до самоорганізації ресурсів в інтелектуальній КФС має справу як із самоорганізацією всередині окремих рівнів системи, так і міжрівневою самоорганізацією $[3,4]$. Для однорівневої самоорганізації активно розвиваються нові підходи та технології з реалізацією в обмежених областях, але масового використання ще не набули.

Дослідження КФС технічного сервісу АТT і МСГТ орієнтовані на розробку моделей і технологій ТОР, що підтримують роботу їх ресурсів і мережевого принципу взаємодії. КФС технічного сервісу відкривають можливості надання нових типів ресурсів при тісній інтеграції їх інформаційних і фізичних підсистем. Аналіз підходів і технологій, спрямованих на підтримку КФС свідчить, що більш перспективним $€$ новий підхід до організації взаємодії ресурсів, заснований на принципах інтелектуалізації та самоорганізації.

Аналіз останніх досліджень і публікацій. Багаторівнева самоорганізація в КФС на сьогоднішній день є малодослідженою [5]. Ситуаційно-орієнтований підхід дозволяє реалізувати самоорганізацію складних транспортних і виробничих систем більш ефективно за рахунок використання принципу конфігурації "згори-донизу". Цей принцип передбачає поділ ресурсів планування КФС на рівні оперативного та стратегічного планування. Причому вироблення спрямованості поведінки ресурсами стратегічного планування призначено 
для ресурсів оперативного планування, а ресурсами оперативного планування - для ресурсів управління фрізичними пристроями [6].

Аналіз функціонування кіберфізичних систем свідчить що вони є прогресивним кроком до створення інтелектуальних систем нового покоління системи технічного сервісу АТТ та МСГТ, що базується на інтелектуальній стратегії їх технічного обслуговування та ремонту [7].

Проблема управління транспортними та виробничими підприємствами безпосередньо пов'язана із сучасною проблемою обробки великою за обсягом бази даних [8], а зростання складності управлінських ситуацій і систем вимагає застосування нових перспективних наукових рішень. Одним з варіантів такого рішення $є$ розподілене інтелектуальне мережеве управління, засноване на застосуванні кіберфізичного підходу при створенні, функціонуванні та удосконаленні транспортних і виробничих систем [9].

В КФС використовують інтелектуальне внутрішньомережеве моделювання [10-13]. Механізм роботи КФС аналогічний механізму роботи мультиагентних систем (МАC) [14]. Разом з тим КФС мають більшу мобільність агентів і включення в середовища фрізичного та інтелектуального просторів розподіленого колективного обчислення.

Формування кіберфізичного підходу дослідження технічного стану систем і агрегатів засобів транспорту доцільним $€$ при використанні методів теорії чутливості $[15,16]$, особливо це стосується використання критеріїв статистичної інформативної та відносної чутливості. Важливим $€$ і еволюційні обчислювання їх життєвого циклу на основі генетичних алгоритмів [17]. При функціонуванні КФС корисним $€$ застосування теоретико-методологічних основ їх побудови [1820]. В КФС технічного сервісу машин увагу слід зосередити на розробці інтелектуальної стратегії технічного обслуговування та ремонту [21], яка $є$ найбільш ефективною з економічної точки зору [22]. Актуальними залишаються методи формування системи транспортного та технологічного забезпечення [23] та концептуальний підхід дослідження КФС [24]. Зазначене стосується логістичних підприємств агропромислового виробництва [25, 26]. Підвищується ефективність функціонування КФС при реалізації фрізико-інформаційного підходу [27], автоматизації і інформатизації транспортних засобів на основі розподільної системи управління мехатронними модулями [28-30]. Кіберфізичний підхід можна покласти в основу організації логістичних центрів в Україні [31] та забезпечування ефективності функціонування транспортних систем [32]. Кіберфізичний підхід передбачає самоорганізацію різного типу транспортних і виробничих систем [33] та дослідження зміни їх стану [34].
Інтелектуальні транспортні і виробничі системи є результатом впровадження кіберфрізичних ефективних технологій [35] та розроблення нової системи організації і управління логістичними потоками різної природи, в т.ч. і сервісних [36].

Застосування внутрішньомережевого інтелектуального моделювання істотно підвищує ефективність управління КФС та їх інфраструктурою, особливо в складних і надзвичайних ситуаціях $[37,38]$. Останнім часом зростає увага до КФС, моделей і методів їх побудови. Проте їх застосування $\epsilon$ недостатнім й необхідні дослідження спеціальних методів, технологій та моделей КФС. Це визначає актуальність аналізу реальних умов функціонування, побудови модельних схем реалізації та розробки алгоритму створення і удосконалення кіберфізичної системи технічного сервісу.

Мета досліджень. Метою даної роботи є забезпечення вибору правильної стратегії самоорганізації ресурсів в кіберфізичних системах технічного сервісу на основі ситуаційно-орієнтованого підходу та досягнення більшої ефективності самоорганізації на різних рівнях в дедуктивному підході при прийнятті рішень щодо операцій за інтелектуальною стратегією ТОР.

Результати досліджень. Інтерес являють дослідження в області організаційної поведінки та управління командами в кіберфізичних системах технічного сервісу щодо поведінки та використання ресурсів. Результати досліджень свідчать, що найбільш ефективними $є$ самоорганізуючі команди в контексті групової поведінки ресурсів (табл. 1).

Таблиця 1. Області компетенцій управління ресурсами (УР) та групи ресурсів (ГР)

\begin{tabular}{|c|c|c|c|c|}
\hline & 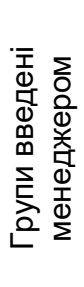 & 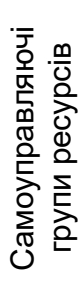 & 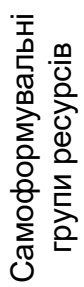 & 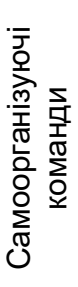 \\
\hline $\begin{array}{l}\text { Формування організацій- } \\
\text { ного контексту }\end{array}$ & YP & УP & УР & ГР \\
\hline Формування групи ресурсів & YP & YP & $\Gamma \mathrm{P}$ & $\Gamma \mathrm{P}$ \\
\hline $\begin{array}{l}\text { Моніторинг і управління } \\
\text { ресурсів }\end{array}$ & УP & ГР & ГР & ГР \\
\hline $\begin{array}{l}\text { Розв'язання завдання, } \\
\text { щодо організації та викори- } \\
\text { стання ресурсів }\end{array}$ & ГР & ГР & ГР & ГР \\
\hline
\end{tabular}

Досліджуючи ступені самоорганізації в кіберфрізичних системах виявлено існування значного ризику того, що дана група ресурсів може бути вибрана за невірною стратегією. Така ситуація не дозволить досягти бажаних цілей. Щоб запобігти 
цього пропонується використати концепцію поведінки самоорганізуючими групами ресурсів і системами на більш високому рівні. Запропоноване $€$ своєчинним поштовхом розвитку ідеї ресурсної самоорганізації в кіберфізичних системах, в т.ч. кіберфізичній системі технічного сервісу.

Оскільки такі системи сприяють створенню і підтримки інтелектуального простору, то їх ресурси використовуються в якості масштабованої інфрраструктури. При цьому кіберфізична система вважається самоорганізуючою, якщо її ресурси здатні автономно відстежувати певну ситуацію, вчасно надавати необхідну інформацію та реалізовувати сервіс за запитом і адаптуватися у відповідності до змін ситуації.
Для забезпечення вибору правильної стратегії самоорганізації ресурсами в ситуаційно-орієнтованому підході функціонування кіберфізичної системи технічного сервісу машин пропонується певна спрямованість поведінки ресурсів, що передається 3 більш високого рівня на низький. Таке управління ресурсами дозволяє досягти більшої ефективності самоорганізації на основі принципу прийняття рішення "згори-донизу", тобто використання дедуктивного підходу.

Схематичне відображення принципів побудови і функціонування кіберфізичної системи технічного сервісу АТТ і МСГТ наведено на рис.1. Зазначені взаємодії базуються на інфраструктурі, що забезпечує зв'язок, обчислення, управління та об'єднує сенсори, обчислювальні пристрої, сервіси та засоби комунікацій.

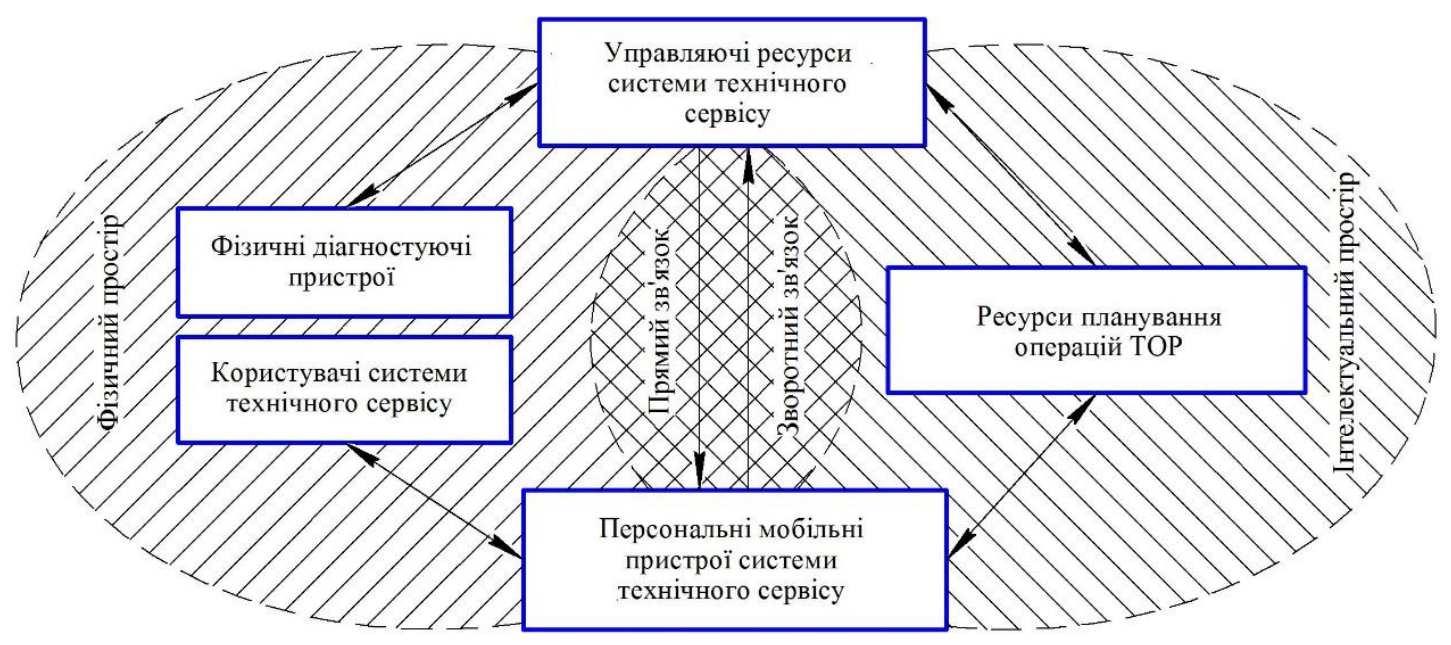

Рис. 1 Схематичне відображення принципів побудови і функціонування кіберфізичної системи технічного сервісу

В КФС спостерігаються самоорганізації верхнього і нижнього рівня та внутрішнього рівня самоорганізації ресурсів. Внутрішньорівнева самоорганізація ресурсів КФС технічного сервісу включає наступні компоненти інформації:

- пізнання, тобто створення суб'єктивного ситуаційно-залежної інформації;

- комунікації, тобто об'єктивізація і суб'єктивізація інформації;

- синергетична кооперація, тобто створення нової об'єктивної інформації.

Ефективне використання індивідуально отриманої ситуаційно-залежної суб'єктивної інформації в кіберфізичній системі технічного сервісу досягається за допомогою процесів координації та кооперації. Об'єктивна інформація зберігається в формалізованому вигляді і дозволяє домогтися відносин, які не залежать від просторово-часової спрямованості.

Для досягнення внутрішньорівневої самоорганізації ресурсів кіберфізичної системи техніч- ного сервісу, її компоненти повинні бути ініціативними, обізнаними, активними і мати соціальну орієнтованість. Ресурси, що є частиною кіберфізичної системи технічного сервісу, змінюють навколишнє середовище, що призводить до зміни поведінки деяких груп ресурсів системи. Виявлено, що індивідуальна поведінка ресурсів частково визначається зовнішнім середовищем, на яке вони впливають. Такий вплив визначається нормами їх поведінки. 3 цією метою розробляються протоколи взаємодії ресурсів на основі BarterCast [39]. В підході використовуються наступні ідеї:

- кожен ресурс будує свою мережу, що охоплює всі можливі варіанти взаємодії з іншими ресурсами;

- репутація окремо взятого ресурсу залежить від репутації інших ресурсів, що знаходяться між даним ресурсом і ресурсом, з яким здійснюється взаємодія. 
Концепція ситуаційно-орієнтованого підходу дає можливість схематично відобразити рівні самоорганізації ресурсів з ситуаціями, які склалися в кіберфізичній системі технічного сервісу (рис. 2).

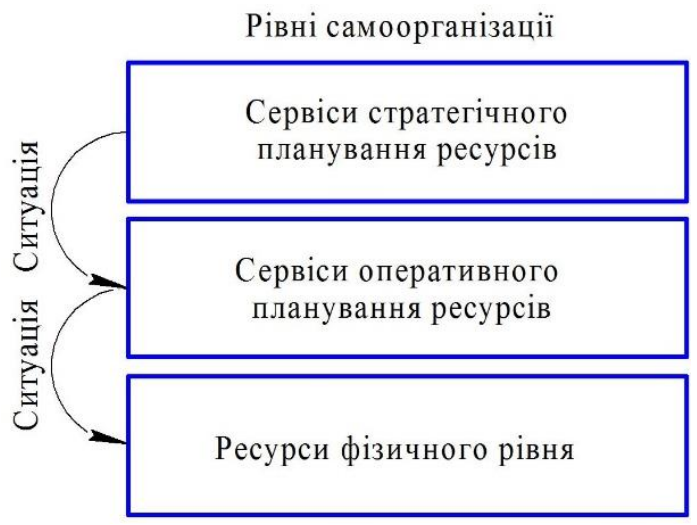

a

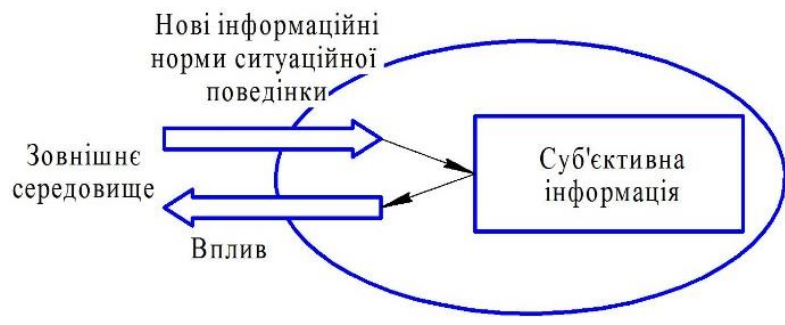

6

Рис. 2 Схематичне відображення концепції ситуаційно-орієнтованого підходу в кіберфізичній системі технічного сервісу: ситуації, сервіси, ресурси та їх рівні самоорганізації (a); внутрішньорівнева самоорганізація(б)

Зазначимо, що через ідентичність структур і моделей самоорганізації на всіх рівнях генерації ситуацій поведінки груп ресурсів здійснюються на кожному рівні. Разом з тим технологічна здатність взаємодії ресурсів підтримується використанням існуючих загальних стандартів.

Одним 3 варіантів реалізації технології інтелектуальних просторів в кіберфізичній системі технічного сервісу АТТ і МСГТ $є$ платорорма SmartМ3. Вона дозволяє створити інфраструктуру, на основі якої розподілені інформаційно-управлінські системи можуть будувати свої інтелектуальні простори, в яких здійснюється взаємодія ресурсів (рис. 1). Взаємодія користувачів мобільних пристроїв і ресурсів кіберфрізичної системи технічного сервісу машин відбувається також в інтелектуальному просторі, але керуючі впливи передаються ресурсами в фрізичний простір.

Smart-M3 ґрунтується на концепції семантичний Веб, основними положеннями якої $€$ незалежність від конкретних виробників, обладнання, області застосування і можливість обміну інформацією між різними програмними модулями за допомогою простого і загальнодоступного інфрормаційного брокера. Завдяки використанню концепції семантичний Веб обмін інформацією між учасниками просторів може здійснюватися на основі протоколу HTTP (Hyper Text TransferProtocol) 3 використанням уніфікованих ідентифікаторів ресурсів (Uniform Resource Identifier - URI) [40]. Що стосується НТTР, то це основний протокол передачі гіпертексту, який використовується для транспортування даних сайтів. Дія стандарту основана на клієнт-серверній технології: клієнт відправляє запит на сервер, який виконує його і висилає результат клієнту. Перехід на основний протокол відбувається після реєстрації домену.

Загальну структурну схему платформи SmartМ3 можливо представити у вигляді (рис. 3).

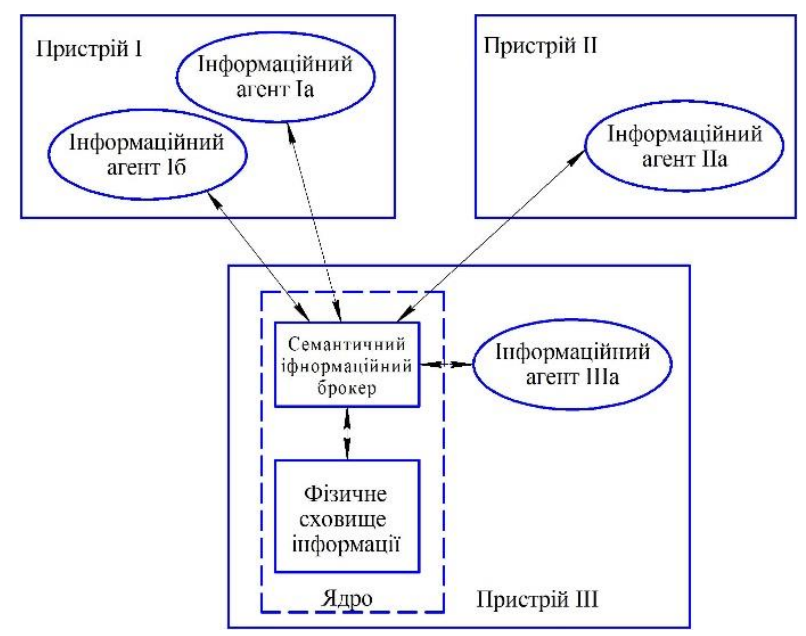

Рис. 3. Структурна схема платформи Smart-M3

Можна бачити, що ядро системи має два елементи: семантичний інформаційний брокер (Semantic Information Broker - SIB) і фрізичне сховище інформації. SIB надає доступ інформаційним агентам до сховища інформації, забезпечуючи їх такими функціями обробки інформації як вставка, витяг, редагування, видалення та підписка на зміну інформації. У сховищі вся інформація зберігається як семантична мережа, яка задовольняє вимоги стандарту RDF (Resource Description Framework) [41]. При цьому вузли i дуги мають уніфіковані ідентифікатори ресурсів. Кожний RDF $€$ твердженням, що описується трійкою "суб'єкт - предикат - об'єкт", а інформаційними об'єктами є програмні модулі.

В КФС технічного сервісу машин відбувається запуск призначеного для користувача додатків і вибір параметрів виконання сценарію. Слід зазначити, що сценарій передбачає взаємодію сервісів і генерацію спільної тенденції. При 
виникненні спірної ситуації призначений для користувача сервіс виводить повідомлення про неможливість виконання сценарію з необхідними параметрами. За згодою користувача нові характеристики тенденції, що склалася, публікуються в інтелектуальному просторі і відбувається надання послуг з технічного обслуговування і ремонту кіберфізичної системи технічного сервісу.

\section{Висновки}

1. З'ясування сутності принципів побудови і функціонування кіберфізичної системи дало можливість запропонувати схематичне відображення кіберфізичної системи технічного сервісу.

2. Оскільки кіберфізична система вважається саморганізуючою, а її ресурси здатні відстежувати певні ситуації і вчасно надавати необхідну інформацію та необхідні сервіси за запитом і адаптуватися при зміні ситуацій, то спрямованість поведінки кіберфізичної системи технічного сервісу та опосередковане управління нею пропонується здійснювати на основі ситуаційно-орієнтованого підходу.

3. Побудовано схематичне відображення концепції ситуаційно-орієнтованого підходу в кіберфізичній системі технічного сервісу машин. 3'ясовано сутність самоорганізацій верхнього і нижнього рівнів, а також внутрішньорівневої самоорганізації. Показано, що взаємодія користувача мобільних пристроїв і ресурсів відбувається в інтелектуальному просторі, а управлінські впливи передаються ресурсами в фрізичний простір.

4. Виявлено, що одним з варіантів реалізації технології інтелектуальних просторів в кіберфізичній системі технічного сервісу $\epsilon$ платформа Smart-M3, яка ґрунтується на концепції семантичний Веб. Схематично представлено загальну структуру платформи Smart-M3. В структурі наявні пристрої, інформаційні агенти, семантичний інформаційний брокер $\mathrm{SiB}$ та фрізичне сховище інформації. Розглянуто функції та роль кожного 3 цих компонентів.

5. Саморганізуюча кіберфізична система технічного сервісу реагує на зміни в фрізичному просторі шляхом децентралізації прийняття рішень щодо поведінки фрізичних пристроїв при відсутності зовнішнього управління. Це свідчить про особливу стійкість таких систем до зовнішніх впливів та її здатність до динамічної адаптації при забезпеченні їх функціонування.

6. На основі концепції семантичний Веб обмін інформацією між учасниками інтелектуальних та фрізичних просторів здійснюється на основі протоколу НТТР з використанням уніфікованих індексаторів ресурсів.

\section{Література:}

1. Atzori L., lera A., Morabito G. The Internet of things: a survey // Computer Networks. 2010. Vol. 54, no. 15. P. 2787 - 2805.
2. Horvath I., Gerritsen B.H.M. Cyber-Physical Systems: Concepts, technologies and implementation principles // Proceedings of TMCE 2012 / Eds. by I. Horvath, Z. Rusak, A. Albers, M. Behrendt. 2012. P. 19 - 36.

3. Serugendo G.D.M., Gleizes M.-P., Karageorgos A. Self-Organisation and Emergence in MAS: an overview // Informatica. 2006. Vol. 30. P. $45-54$.

4. Honkola J., Laine H., Brown R., Tyrkkö O. Smart-M3 Information Sharing Platform, 2010 IEEE Symposium on Computers and Communications (ISCC), Italy 2010. P. 1041 - 1046.

5. Hackman J.R. The design of work teams // Handbook of Organizational Behavior / Ed. by J.W. Lorch. NJ, Upper Saddle River: Prentice Hall, 1987.

6. Голембо В., Бочкарьов О. Підходи до побудови концептуальних моделей кіберфізичних систем. Вісник Національного університету "Львівська політехніка". Серія: Комп'ютерні науки та інформаційні технології. - Львів : Видавництво Львівської політехніки, 2017. № 864. С. 168 - 178.

7. Аулін В.В., Гриньків А.В., Ляшук О.Л., Великодний Д.О. Принципові основи організації та вдосконалення системи технічного сервісу транспортних машин. Перспективи і тенденції розвитку конструкцій та технічного сервісу с-х машин і знарядь: збірник тез V Всеукраїнської науковопрактичної конференції, 28-29 березня 2019 р. Житомир: Житомирський агротехнічний коледж, 2019. C. 245 - 248.

8. Чехарин Е. Е. Большие данные: большие проблемы. Перспективы науки и образования. 2016. № 3. C. 7 - 11.

9. Khaitan et al. Design Techniques and Applications of Cyber Physical Systems: A Survey, IEEE Systems Journal, 2014, 9(2), pp.1 - 16.

10. Jianjun S.et al.The analysis of traffic control Cyber-physical systems. Procedia-Social and Behavioral Sciences. 2013. T. 96. C. 2487 - 2496.

11. Ван Чунжі, Яцишин С. П., Лиса О. В., Мідик А.-В. В. Кіберфрізичні системи та їх програмне забезпечення. Вимірювальна техніка та метрологія: міжвідомчий науково-технічний збірник. Львів: Видавництво Львівської політехніки. 2018. Том 79. № 1. С. 34 - 38.

12. Мейтус В. Ю., Морозова Г. І, Таран Л. Ю., Козлова В. П., Майданюк Н. В. Кіберфрізичні системи ж основа інтелектуалізації "Розумних" підприємств. Управляющие системы и машины. 2019. №4. C.14 - 26.

13. Лёвин Б.А., Цветков В.Я. Киберфизические системы в управлении транспортом. МИР ТРАНСПОРТА, 2018, том 16, № 2, С. 138 - 145.

14. Розенберг И. Н., Цветков В. Я. Применение мультиагентных систем в интеллектуальных логистических системах. Международный журнал экспериментального образования. 2012. №6. C. $107-109$. 
15. Аулін В.В., Гриньків А.В. Теоретичний аналіз діагностичних параметрів технічного стану систем та агрегатів засобів транспорту за допомогою методів теорії чутливості. Науковий вісник Національного університету біоресурсів і природокористування України. Серія: техніка та енергетика АПК. 2017. Вип. 262. С. 227 - 239.

16. Аулін В.В., Гриньків А.В. Метод визначення тенденцій зміни технічного стану засобів транспорту з використанням критеріїв статистичної інфрормативності та відносної чутливості. Крамаровські читання: зб. тез доповідей V Міжнародної науково-технічної конференції, 22-23 лют. 2018 р., К.: Видавничий центр НУБіП України, 2018. C. 132 - 135.

17. Аулин В.В., Панков А.А. Эволюционное вычисление жизненного цикла технических средств на основе генетических алгоритмов. Вісник інж. академії України. 2017. №2. С.116 - 119.

18. Аулин В.В., Великодний Д.О., Дьяченко В.О. Теоретико-методологічні основи побудови транспортно-логістичних систем. Проблеми і перспективи розвитку автомобільного транспорту: Матеріали VI-ої міжнародної науково-практичної інтернет-конференції, 12-13 квітня 2018 року. Вінниця: ВНТУ, 2018. С.9 - 10.

19. Аулін В.В. Великодний Д.О., Дьяченко B.О. Оптимізація і управління ресурсами в транспортно-логістичній системі АПК. Міжвузівський збірник "Наукові нотатки". Луцьк: Луцький НТУ, 2018. №62. С. 8 - 11.

20. Аулін В.В., Великодний Д.О., Голуб Д.В., Дьченко В.О. Підвищення ефективності управління логістичним ланцюгом постачання в транспортній системі. Крамаровські читання: зб. тез доповідей VI Міжнародної науково-технічної конференції. 21-22 лют. 2019 р., м. Київ: НУБіП, 2019. C. 195 - 198.

21. Аулин В.В., Замота Т.Н., Замота О.Н., Гринькив А.В. Технико-экономическое обоснование преимущества интеллектуальной стратегии технического обслуживания и ремонта легкового автомобиля. Вісник інж. академії України. 2017. №4. С. 50 - 56.

22. Аулин В.В., Замота Т. М., Гринькив А. В., Замота О. М., Чернай А. Е. Преимущества интеллектуальной стратегии технической эксплуатации с точки зрения экономической эффеектвности. Вісник Харківського національного технічного університету сільського господарства імені Петра Василенка. 2018. Вип. 192. С. 29 - 40.

23. Аулін В.В., Великодний Д.О. Методи формування системи транспортно-технологічного забезпечення в АПК. Транспорт і логістика: проблеми та рішення: збірник наукових праць за матеріалами VIII-ї Міжнародної науково-практичної конференції, 23-25 травня 2018р. Одеса: КУПРІЄНКО СВ, 2018. С. 15 - 17.
24. Аулін В.В., Голуб Д. В., Гриньків А.В. Концептуальний підхід дослідження функціонування транспортних систем. Перспективні напрями розвитку регіональних транспортних та логістичних систем: матеріали Міжнародної науково-практичної конференції, 22-23 травня 2018 р. Харків: ХНАДУ, 2018. С.14 - 17.

25. Аулін В.В., Голуб Д.В., Гриньків А.В. Удосконалення системи транспортного обслуговування підприємств агропромислового виробництва. Загальнодержавний міжвідомчий науково-технічний збірник. Конструювання, виробництво та експлуатація сільськогосподарських машин, Кропивницький: ЦНТУ, 2017. вип. 47, ч.ІІ. С. 3 - 10.

26. Aulin V., Velykodnyi D., Dyachenko V. Concept of development and formation of transportlogistic systems in the agroindustrial complex. Modern Management: Logistics and Education. Monograph. Opole: The Academy of Management and Administration in Opole, 2018. P.165 - 169.

27. Аулін В.В., Голуб Д.В. Реалізація фрізикоінформаційного підходу дослідження проблеми підвищення надійності та ефективності функціонування транспортних систем. Вестник ХНАДУ, 2018. вып. 81. С.21 - 28.

28. Аулин В.В., Панков А.А. Автоматизация и информатизация транспортных средств на основе распределенной системы управления с интеллектуальными мехатронными модулями. Інноваційні технології розвитку та ефективності функціонування автомобільного транспорту: збірник наукових матеріалів міжнародної науково-практичної інтернет-конференції, ЦНТУ м.Кропивницький, Україна, 14-15 листопада 2018 року. Кропивницький. 2018. С.97 - 100.

29. Аулін В.В., Панков А.О, Гриньків А.В., Голуб Д.В., Щеглов А.В. Розробка інтелектуального мехатронного модуля для системи управління дозуванням. Інтегровані інтелектуальні робототехнічні комплекси (IIPTК-2019): збірник тез Дванадцятої міжнародної науково-практичної конференції, 21-22 травня 2019 року, Київ, Україна. К.: HAY, 2019. C.173 - 175.

30. Aulin V.V., Pankov A.O., Zamota T.M., Lyashuk O.L., Hrynkiv A.V., Tykhyi A.A., Kuzyk A. $\mathrm{V}$. Development of mechatronic module for the seeding control system. INMATEH - Agricultural Engineering, 2019. vol. 59, no.3. P. 181 - 188.

31. Aulin V., Pavlenko O., Velikodnyy D., Kalinichenko O, Hrinkiv A., Diychenko V., Dzyura V. Methodological approach to estimation of efficiency of the facing of the stock complex of transport and logistic centers in Ukraine. ICCPT 2019: Current Problems of Transport: Proceedings of the 1st International Scientific Conference, May 28-29, 2019, Ternopil, Ukraine. C.120 - 134.

32. Аулін В.В., Голуб Д.В. Забезпечення ефективності функціонування транспортних систем 
шляхом підвищення надійності структурно-функціональних резервних схем процесу доставки. Наука - виробництву 2019: зб. тез доповідей викладачів, аспірантів та співробітників L наукової конференції, 18 квітня 2019 року. Кропивницький: ЦНТУ, 2019. С. 17 - 20.

33. Аулін В.В., Голуб Д.В., Біліченко В.В., Замуренко А.С. Принципи самоорганізації автомобільних транспортних систем. Проблеми і перспективи розвитку автомобільного транспорту: матеріали VIII-ої міжн. наук.-практичної інтернетконф., 14-15 квітня 2020 року: зб. наук. праць / МОН України, ВНТУ [та ін.]. - Вінниця: ВНТУ, 2020. С.17 - 19.

34. Аулін В.В., Гриньків А.В. Кіберфізичний підхід в дослідження стану технічних систем. Підвищення надійності машин і обладнання. Increase of Machine and Equipment Reliability: матеріали Міжнародної науково-практичної конференції, 15-17 квітня 2020 р. Кропивницький: ЦНТУ, 2020. С.168-169.

35. Аулін В.В., Гриньків А.В., Головатий А.О. Інтелектуальні транспортні системи як результат впровадження інноваційних ефективних технологій. Підвищення надійності машин і обладнання. Increase of Machine and Equipment Reliability: матеріали Міжнародної науково-практичної конференції, 15-17 квітня 2020 р. - Кропивницький: ЦНТУ, 2020. С.207.

36. Аулін В.В., Гриньків А.В., Головатий А.О., Кернус Р.О. Необхідність розроблення нової системи організації та управління логістичними потоками. Підвищення надійності машин і обладнання. Increase of Machine and Equipment Reliability: матеріали Міжнародної науково-практичної конференції, 15-17 квітня 2020 р. Кропивницький: ЦНТУ, 2020. С.236 - 237.

37. Іґнатович А. О. Моделі застосування модифікованих блокових шифрів у кіберфізичних системах. Кіберфізичні системи досягнення та виклики : матеріали I Наукового семінару, 25-26 червня 2015 року, Львів. Національний університет "Львівська політехніка". - Львів: НВФ "Українські технології". 2015. С. 144 - 148.

38. Волков С. Л., Асабашвілі С. Д., Коломієць С. В. Модель оцінки якості життєвого циклу промислових кіберфізичних систем. Збірник наукових праць Одеської державної академії технічного регулювання та якості. 2018, вил. 2 (13). c. 43 - 49 .

39. Meulpolder M., Pouwelse J.A., Epema D.H.J., Sips, H.J. BarterCast: A practical approach to prevent lazy freeriding in P2P networks, IEEE International Symposium on Parallel \& Distributed Processing, 2009, P. 1 - 8.

40. Berners-Lee T., Fielding R., Masinter L. RFC 3986 - Uniform Resource Identifier (URI): Generic Syntax, URL: http://tools.ietf.org/html/rfc3986.
41. Resource Description Framework (RDF), URL: http://www.w3.org/RDF.

\section{References:}

1. Atzori L., Iera A., Morabito G. The Internet of things: a survey // Computer Networks. 2010. Vol. 54, no. 15. P. 2787 - 2805.

2. Horvath I., Gerritsen B.H.M. Cyber-Physical Systems: Concepts, technologies and implementation principles // Proceedings of TMCE 2012 / Eds. by I. Horvath, Z. Rusak, A. Albers, M. Behrendt. 2012. P. 19 - 36.

3. Serugendo G.D.M., Gleizes M.-P., Karage$\operatorname{orgos}$ A. Self-Organisation and Emergence in MAS: an overview // Informatica. 2006. Vol. 30. P. 45 - 54.

4. Honkola J., Laine H., Brown R., Tyrkkö O. Smart-M3 Information Sharing Platform, 2010 IEEE Symposium on Computers and Communications (ISCC), Italy 2010. P. 1041 - 1046.

5. Hackman J.R. The design of work teams // Handbook of Organizational Behavior / Ed. by J.W. Lorch. NJ, Upper Saddle River: Prentice Hall, 1987.

6. Holembo V., Bochkarov O. Pidkhody do pobudovy kontseptualnykh modelei kiberfizychnykh system. Visnyk Natsionalnoho universytetu "Lvivska politekhnika". Seriia: Kompiuterni nauky ta informatsiini tekhnolohii. - Lviv : Vydavnytstvo Lvivskoi politekhniky, 2017. № 864. S. 168 - 178.

7. Aulin V.V., Hrynkiv A.V., Liashuk O.L., Velykodnyi D.O. Pryntsypovi osnovy orhanizatsii ta vdoskonalennia systemy tekhnichnoho servisu transportnykh mashyn. Perspektyvy i tendentsii rozvytku konstruktsii ta tekhnichnoho servisu s-kh mashyn i znariad: zbirnyk tez $\mathrm{V}$ Vseukrainskoi naukovo-praktychnoi konferentsii, 28-29 bereznia 2019 r. Zhytomyr: Zhytomyrskyi ahrotekhnichnyi koledzh, 2019. S. 245 - 248.

8. Cheharin E. E. Bolshie dannyie: bolshie problemyi. Perspektivyi nauki i obrazovaniya. 2016. № 3. S. 7 - 11.

9. Khaitan et al. Design Techniques and Applications of Cyber Physical Systems: A Survey, IEEE Systems Journal, 2014, 9(2), pp.1 - 16.

10. Jianjun S.et al.The analysis of traffic control Cyber-physical systems. Procedia-Social and Behavioral Sciences. 2013. T. 96. C. 2487 - 2496.

11. Van Chunzhi, Yatsyshyn S. P., Lysa O. V., Midyk A.-V. V. Kiberfizychni systemy ta yikh prohramne zabezpechennia. Vymiriuvalna tekhnika ta metrolohiia: mizhvidomchyi naukovo-tekhnichnyi zbirnyk. Lviv: Vydavnytstvo Lvivskoi politekhniky. 2018. Tom 79. № 1. S. 34 - 38.

12. Meitus V. Yu., Morozova H. I, Taran L. Yu., Kozlova V. P., Maidaniuk N. V. Kiberfizychni systemy zh osnova intelektualizatsii "Rozumnykh" pidpryiemstv. Upravlyayuschie sistemyi i mashinyi. 2019. №4. S.14 - 26.
ISSN 2311-1828

http://enm.khntusg.com.ua
Інженерія природокористування, 2020, №3(17), с. 101 - 110

Engineering of nature management, 2020,\#3(17), p. $101-110$ 
13. LYovin B.A., Tsvetkov V.Ya. Kiberfizicheskie sistemyi $v$ upravlenii transportom. MIR TRANSPORTA, 2018, tom 16, № 2, S. 138 - 145.

14. Rozenberg I. N., Tsvetkov V. Ya. Primenenie multiagentnyih sistem $\mathrm{v}$ intellektualnyih logisticheskih sistemah. Mezhdunarodnyiy zhurnal eksperimentalnogo obrazovaniya. 2012. №6. S. 107 - 109.

15. Aulin V.V., Hrynkiv A.V. Teoretychnyi analiz diahnostychnykh parametriv tekhnichnoho stanu system ta ahrehativ zasobiv transportu za dopomohoiu metodiv teorii chutlyvosti. Naukovyi visnyk Natsionalnoho universytetu bioresursiv i pryrodokorystuvannia Ukrainy. Seriia: tekhnika ta enerhetyka APK. 2017. Vyp. 262. S. 227 - 239.

16. Aulin V.V., Hrynkiv A.V. Metod vyznachennia tendentsii zminy tekhnichnoho stanu zasobiv transportu $\mathrm{z}$ vykorystanniam kryteriiv statystychnoi informatyvnosti ta vidnosnoi chutlyvosti. Kramarovski chytannia: zb. tez dopovidei $V$ Mizhnarodnoi naukovo-tekhnichnoi konferentsii, 22 - 23 liut. 2018 r., K.: Vydavnychyi tsentr NUBiP Ukrainy, 2018. S. 132 - 135.

17. Aulin V.V., Pankov A.A. Evolyutsionnoe vyichislenie zhiznennogo tsikla tehnicheskih sredstv na osnove geneticheskih algoritmov. Visnyk inzh. akademii Ukrainy. 2017. №2. S.116 - 119.

18. Aulin V.V., Velykodnyi D.O., Diachenko V.O. Teoretyko-metodolohichni osnovy pobudovy transportno-lohistychnykh system. Problemy i perspektyvy rozvytku avtomobilnoho transportu: Materialy VI-oi mizhnarodnoi naukovo-praktychnoi internet-konferentsii, 12 - 13 kvitnia 2018 roku. Vinnytsia: VNTU, 2018. S.9 - 10.

19. Aulin V.V. Velykodnyi D.O., Diachenko V.O. Optymizatsiia i upravlinnia resursamy $v$ transportnolohistychnii systemi APK. Mizhvuzivskyi zbirnyk "Naukovi notatky". Lutsk: Lutskyi NTU, 2018. №62. S.8 - 11.

20. Aulin V.V., Velykodnyi D.O., Holub D.V., Diachenko V.O. Pidvyshchennia efektyvnosti upravlinnia lohistychnym lantsiuhom postachannia $v$ transportnii systemi. Kramarovski chytannia: zb. tez dopovidei VI Mizhnarodnoi naukovo-tekhnichnoi konferentsii. 21-22 liut. 2019 r., m. Kyiv: NUBiP, 2019. S. 195 - 198.

21. Aulin V.V., Zamota T.N., Zamota O.N., Grinkiv A.V. Tehniko-ekonomicheskoe obosnovanie preimuschestva intellektualnoy strategii tehnicheskogo obsluzhivaniya i remonta legkovogo avtomobilya. Visnyk inzh. akademii Ukrainy. 2017. №4. S.50 - 56.

22. Aulin V.V., Zamota T.Y., Grinkiv A.V., Zamota O.M., Chernay A.E. Preimuschestva intellektualnoy strategii tehnicheskoy ekspluatatsii s tochki zreniya ekonomicheskoy effektivnosti. Visnyk Kharkivskoho natsionalnoho tekhnichnoho universytetu silskoho hospodarstva imeni Petra Vasylenka. 2018. Vyp. 192. S. 29 - 40.
23. Aulin V.V., Velykodnyi D.O. Metody formuvannia cystemy transportno-tekhnolohichnoho zabezpechennia $v$ APK. Transport i lohistyka: problemy ta rishennia: zbirnyk naukovykh prats za materialamy VIII-yi Mizhnarodnoi naukovopraktychnoi konferentsii, 23-25 travnia 2018r. Odesa: KUPRIleNKO SV, 2018. S. 15 - 17.

24. Aulin V.V., Holub D. V., Hrynkiv A.V. Kontseptualnyi pidkhid doslidzhennia funktsionuvannia transportnykh system. Perspektyvni napriamy rozvytku rehionalnykh transportnykh ta lohistychnykh system: materialy Mizhnarodnoi naukovo-praktychnoi konferentsii, 22-23 travnia 2018 r. Kharkiv: KhNADU, 2018. S.14 - 17.

25. Aulin V.V., Holub D.V., Hrynkiv A.V. Udoskonalennia systemy transportnoho obsluhovuvannia pidpryiemstv ahropromyslovoho vyrobnytstva. Zahalnoderzhavnyi mizhvidomchyi naukovotekhnichnyi zbirnyk. Konstruiuvannia, vyrobnytstvo ta ekspluatatsiia silskohospodarskykh mashyn, Kropyvnytskyi: TsNTU, 2017. vyp. 47, ch.II. S. 3 - 10.

26. Aulin V., Velykodnyi D., Dyachenko V. Concept of development and formation of transportlogistic systems in the agroindustrial complex. Modern Management: Logistics and Education. Monograph. Opole: The Academy of Management and Administration in Opole, 2018. P.165 - 169.

27. Aulin V.V., Holub D.V. Realizatsiia fizykoinformatsiinoho pidkhodu doslidzhennia problemy pidvyshchennia nadiinosti ta efektyvnosti funktsionuvannia transportnykh system. Vestnyk KhNADU, 2018. vip. 81. S.21 - 28.

28. Aulin V.V., Pankov A.A. Avtomatizatsiya i informatizatsiya transportnyih sredstv na osnove raspredelennoy sistemyi upravleniya $\mathrm{s}$ intellektualnyimi mehatronnyimi modulyami. Innovatsiini tekhnolohii rozvytku ta efektyvnosti funktsionuvannia avtomobilnoho transportu: zbirnyk naukovykh materialiv mizhnarodnoi naukovopraktychnoi internet-konferentsii, TsNTU m.Kropyvnytskyi, Ukraina, 14-15 lystopada 2018 roku. Kropyvnytskyi. 2018. S.97 - 100.

29. Aulin V.V., Pankov A.O, Hrynkiv A.V., Holub D.V., Shchehlov A.V. Rozrobka intelektualnoho mekhatronnoho modulia dlia systemy upravlinnia dozuvanniam. Intehrovani intelektualni robototekhnichni kompleksy (IIRTK-2019): zbirnyk tez Dvanadtsiatoi mizhnarodnoi naukovopraktychnoi konferentsii, 21-22 travnia 2019 roku, Kyiv, Ukraina. K.: NAU, 2019. S.173 - 175.

30. Aulin V.V., Pankov A.O., Zamota T.M., Lyashuk O.L., Hrynkiv A.V., Tykhyi A.A., Kuzyk A. $\mathrm{V}$. Development of mechatronic module for the seeding control system. INMATEH - Agricultural Engineering, 2019. vol. 59, no.3. P. 181 - 188.

31. Aulin V., Pavlenko O., Velikodnyy D., Kalinichenko O, Hrinkiv A., Diychenko V., Dzyura V. Methodological approach to estimation of efficiency 
of the facing of the stock complex of transport and logistic centers in Ukraine. ICCPT 2019: Current Problems of Transport: Proceedings of the 1st International Scientific Conference, May 28-29, 2019, Ternopil, Ukraine. C.120 - 134.

32. Aulin V.V., Holub D.V. Zabezpechennia efektyvnosti funktsionuvannia transportnykh system shliakhom pidvyshchennia nadiinosti strukturnofunktsionalnykh rezervnykh skhem protsesu dostavky. Nauka - vyrobnytstvu 2019: zb. tez dopovidei vykladachiv, aspirantiv ta spivrobitnykiv $L$ naukovoi konferentsii, 18 kvitnia 2019 roku. Kropyvnytskyi: TsNTU, 2019. S. 17 - 20.

33. Aulin V.V., Holub D.V., Bilichenko V.V., Zamurenko A.S. Pryntsypy samoorhanizatsii avtomobilnykh transportnykh system. Problemy i perspektyvy rozvytku avtomobilnoho transportu: materialy VIII-oi mizhn. nauk.-praktychnoi internet-konf., 1415 kvitnia 2020 roku: zb. nauk. prats / MON Ukrainy, VNTU [ta in.]. - Vinnytsia: VNTU, 2020. S.17 - 19.

34. Aulin V.V., Hrynkiv A.V. Kiberfizychnyi pidkhid $v$ doslidzhennia stanu tekhnichnykh system. Pidvyshchennia nadiinosti mashyn i obladnannia. Increase of Machine and Equipment Reliability: materialy Mizhnarodnoi naukovo-praktychnoi konferentsii, 15-17 kvitnia 2020 r. Kropyvnytskyi: TsNTU, 2020. S.168 - 169.

35. Aulin V.V., Hrynkiv A.V., Holovatyi A.O. Intelektualni transportni systemy yak rezultat vprovadzhennia innovatsiinykh efektyvnykh tekhnolohii. Pidvyshchennia nadiinosti mashyn i obladnannia. Increase of Machine and Equipment Reliability: materialy Mizhnarodnoi naukovo- praktychnoi konferentsii, 15-17 kvitnia 2020 r. Kropyvnytskyi: TsNTU, 2020. S.207.

36. Aulin V.V., Hrynkiv A.V., Holovatyi A.O., Kernus R.O. Neobkhidnist rozroblennia novoi systemy orhanizatsii ta upravlinnia lohistychnymy potokamy. Pidvyshchennia nadiinosti mashyn i obladnannia. Increase of Machine and Equipment Reliability: materialy Mizhnarodnoi naukovopraktychnoi konferentsii, 15-17 kvitnia 2020 r. Kropyvnytskyi: TsNTU, 2020. S.236 - 237.

37. Ignatovych A. O. Modeli zastosuvannia modyfikovanykh blokovykh shyfriv u kiberfizychnykh systemakh. Kiberfizychni systemy dosiahnennia ta vyklyky : materialy I Naukovoho seminaru, 25-26 chervnia 2015 roku, Lviv. Natsionalnyi universytet "Lvivska politekhnika". - Lviv: NVF "Ukrainski tekhnolohii". 2015. S. 144 - 148.

38. Volkov S. L., Asabashvili S. D., Kolomiiets S. V. Model otsinky yakosti zhyttievoho tsyklu promyslovykh kiberfizychnykh system. Zbirnyk naukovykh prats Odeskoi derzhavnoi akademii tekhnichnoho rehuliuvannia ta yakosti. 2018, vyl. 2 (13). s. 43 - 49.

39. Meulpolder M., Pouwelse J.A., Epema D.H.J., Sips, H.J. BarterCast: A practical approach to prevent lazy freeriding in P2P networks, IEEE International Symposium on Parallel \& Distributed Processing, 2009, P. 1 - 8.

40. Berners-Lee T., Fielding R., Masinter L. RFC 3986 - Uniform Resource Identifier (URI): Generic Syntax, URL: http://tools.ietf.org/html/rfc3986.

41. Resource Description Framework (RDF), URL: http://www.w3.org/RDF.

\section{Аннотация}

\section{Принципы построения и функционирования киберфизической системы технического сервиса автотранспортной и мобильной сельскохозяйственной техники}

\section{В.В. Аулин, А.В. Гринькив, С.В. Лысенко, А.Н. Ливицкий, А.О. Головатый, В.А. Дьяченко}

В работе представлена многоуровневая самоорганизация ресурсов киберфизической системы технического сервиса на основе ситуационно-ориентированного подхода. В основе подхода положена концепция, что касается организационного поведения ресурсов верхнего уровня и обеспечения их учета при самоорганизации ресурсов нижнего уровня. Выяснено, что доступ к информации о ресурсах киберфизической системы технического сервиса обеспечивается использованием технологии интеллектуальных пространств. Реализацию ситуационно-ориентированного подхода осуществлено на примере сценария предоставления услуг в сервисном обслуживании автотранспортной и мобильной сельскохозяйственной техники с участием фризических устройств, контролируемых управляющими ресурсами, и ресурсов планирования, отвечающие за генерацию направленности поведения управляющих ресурсов. Отмечено, что технология интеллектуального пространства построена на открытой платформе Smart-M3 и представлена ее структура. Сама платформа основывается на концепции семантический Веб. Показано, что обмен информацией между участниками пространств осуществляется на основе протокола НТТР.

Ключевые слова: киберфизическая система, технический сервис, ситуационно-ориентированный подход, самоорганизация, физическое пространство, интеллектуальное пространство, ресурс 


\begin{abstract}

$$
\begin{aligned}
& \text { Principles of construction and functioning } \\
& \text { of a cyber-physical system of technical service }
\end{aligned}
$$$$
\text { of motor transport and mobile agricultural managers }
$$

\section{V.V. Aulin, A.V. Hrinkiv, S.V. Lysenko, A.N. Livitsky, A.O. Golovaty, V.A. Dyachenko}

The paper presents a multi-level self-organization of resources of a cyber-physical system of technical service based on a situational-oriented approach. The approach is based on the concept that concerns the organizational behavior of the upper-level resources and ensuring their accounting in the self-organization of the lower-level resources. It has been found that access to information about the resources of the cyberphysical system of the technical service is provided by using the technology of intelligent spaces. The implementation of the situationally-oriented approach is carried out on the example of a scenario for the provision of services in the maintenance of motor transport and mobile agricultural machinery with the participation of physical devices controlled by resource managers and planning resources responsible for generating the direction of the behavior of control resources. It is noted that the technology of intelligent space is built on the open platform Smart-M3 and its structure is presented. The platform itself is based on the concept of the Semantic Web. It is shown that the exchange of information between space participants is based on the HTTP protocol.
\end{abstract}

Keywords: cyber-physical system, technical service, situation-oriented approach, self-organization, physical space, intellectual space, resource

\title{
Бібліографічне посилання/ Bibliography citation: Harvard
}

Aulin, V. V. et al. (2020) 'Principles of construction and functioning of a cyber-physical system of technical service of motor transport and mobile agricultural managers', Engineering of nature management, (3(17), pp. $101-110$.

Подано до редакції / Received: 12.09.2020 